\title{
Proefschrift
}

\section{Vertical integration in medical education: Studies on the required basic science knowledge and the concept of context}

Koens F (19 april 2005). Vertical integration in medical education: Studies on the required basic science knowledge and the concept of context. Universiteit Utrecht. Promotoren: prof. dr. Th.J. ten Cate, prof. dr. K.V. Mann (Dalhousie University, Halifax, Canada). Co-promotor: dr. E.J.F.M. Custers. Enschede: Febodruk; 2005. 158 pagina's. ISBN 90-393-1287-7.

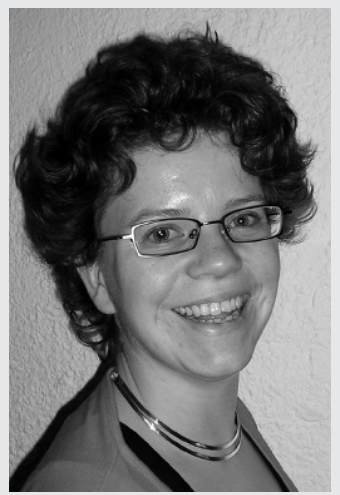

\section{Naam Franciska Koens}

1995 - $2000 \quad$ Medische Biologie, Vrije Universiteit Amsterdam.

2000 - 2005 Promotieonderzoek, Universiteit Utrecht.

2005 - heden Werkzaam aan het Onderwijsinstituut VUmc te

Amsterdam als onderzoeker medisch onderwijs.

Onderzoeksthema's: leren in een klinische context, basisvakken.

Wanneer in een curriculum biomedische kennis en klinische kennis geïntegreerd worden (verticale integratie), dienen zich in ieder geval twee vragen aan:

1.Hoeveel biomedische kennis is vereist voor geneeskundestudenten?

2.In welke context kunnen we (biomedische) kennis het beste presenteren?

In dit proefschrift zijn beide vragen onderzocht.

Het vereiste biomedische kennisniveau. Om de eerste vraag te beantwoorden, zijn twee onderzoeken uitgevoerd naar de mening van klinisch en biomedisch docenten over het vereiste biomedische kennisniveau van basisartsen. Uit het onderzoek blijkt dat clinici en basisvakdocenten anders oordelen over de vereiste biomedische kennis voor basisartsen. Basisvakdocenten vinden in vergelijking met clinici dat geneeskundestudenten meer parate kennis nodig hebben, ook op de diepere kennisniveaus (bijv. cellulair/moleculair). Daarnaast blijkt dat klinisch docenten en arts-assistenten biomedische kennis uit een voortgangstoets voor parate kennis voor $42.5 \%$ beschouwen als parate kennis. Deze vragen zijn geformuleerd door basisvakdocenten die hierover een andere opvatting blijken te hebben. Kortom, clinici en biomedici verschillen van mening over de vereiste biomedische kennis voor basisartsen.

Dimensional Context Model. Naast de studies naar het vereiste biomedische kennisniveau van de basisarts, is ook onderzoek gedaan naar de context waarin kennis gepresenteerd kan worden. Voordat deze studies hierin beschreven worden, wordt eerst het concept 'leren in de klinische context' uitgediept. Wanneer we spreken over de klinische context, bedoelen we niet allemaal hetzelfde. Klinische vaardigheden kunnen worden geleerd in de klinische context en biomedische kennis kan in de klinische con- 
text gepresenteerd worden, maar de klinische context in beide voorbeelden is erg verschillend.

Centraal in het proefschrift staat het Dimensional Context Model, waarin een analyse is gemaakt van de klinische context. Het model onderscheidt context in drie verschillende dimensies, namelijk een fysische, een cognitieve en een motivationele (commitment) dimensie. De fysische dimensie richt zich op de omgeving waarin de student zich bevindt, de cognitieve dimensie richt zich op de vraag in hoeverre de context bijdraagt aan de betekenis van de leerstof en ten slotte richt de motivationele dimensie zich op de mate waarin de context betrokkenheid opwekt bij de student voor de leertaak. De laatste dimensie hangt samen met motivatie en verantwoordelijkheid. Elk van deze dimensies kan in een bepaalde mate voorkomen (van gereduceerd tot verrijkt). Binnen de kaders van het model is onderzoek gedaan naar de invloed van de verschillende contextdimensies op het leren.

Fysische contextdimensie. Voor de fysische dimensie is onderzocht welk effect de omgeving heeft op het onthouden van kennis. De hypothese is dat kennis beter wordt gereproduceerd als dit plaatsvindt in dezelfde omgeving als waar dit geleerd is. Vijfdejaars geneeskundestudenten luisterden in een onderwijsomgeving of in een ziekenhuisomgeving naar een bandje met losse woorden en een patiëntencasus over galstenen. In de ziekenhuisomgeving was ook een simulatiepatiënte aanwezig die gelijkenis vertoonde met de patiënte op het bandje. $\mathrm{Na}$ het beluisteren werd de studenten gevraagd alles op te schrijven wat ze zich konden herinneren, hetzij in dezelfde omgeving waar ze geluisterd hadden naar het bandje, hetzij in de andere omgeving. We vonden geen significante verschillen in kennisreproductie tussen de groepen die dezelfde omgeving hebben ervaren en groepen die twee verschillende omgevingen hebben gezien. Het lijkt er echter wel op dat de kliniek als leeromgeving een betere reproductie van de patiëntencasus oplevert - ongeacht waar het gereproduceerd wordt.

Cognitieve contextdimensie. In het experiment naar de cognitieve dimensie is onderzocht of het bestuderen van een biomedische tekst met een klinische context (een video en een patiëntencasus) leidt tot een beter leerresultaat dan het bestuderen van deze tekst zonder de klinische context. Eerstejaars geneeskundestudenten bestudeerden met of zonder een voorafgaande klinische context een biomedische tekst. Deelnemers die geen klinische context aangeboden kregen, kregen extra tijd om de biomedische tekst te bestuderen in de tijd die nodig was voor de klinische context. Direct na afloop en na één week maakten de studenten een toets over de biomedische tekst. Deelnemers die studeerden met een klinische context scoorden hoger op de kennistoets direct na de interventie en een week na de interventie, maar het verschil met de studenten die studeerden zonder klinische context was niet significant.

Motivationele contextdimensie. In het laatste experiment naar de motivationele dimensie is onderzocht of een context die gericht is op een hogere mate van motivatie voor een leertaak leidt tot een betere prestatie bij de toetsing hiervan. Deze hogere mate van motivatie is verkregen door studenten een gynaecologische tekst te laten bestuderen vlak voordat zij het practicum inwendig onderzoek bij een docent gynaecologisch onderwijs uitvoerden. Studenten die een minder hoge mate van motivatie meemaakten, bestudeerden deze tekst tenminste één week voor het uitvoeren van dit onderzoek. Na het bestuderen van de tekst maakten de deelnemers een toets. We vonden een significant verschil, waarbij studenten bij een hogere motivationele dimensie beter presteerden. Echter, bij een post-hocvergelijking tussen de beide groepen op basis van hun voortgangstoets score bleek dat de groepen niet vergelijkbaar waren en de studenten die de tekst bestudeerden in de hoge motivationele dimensie al de betere studenten waren.

Leren in een klinische context. De resultaten geven niet eenduidig aan dat een meer verrijkte vorm van een klinische context (in de zin van fysisch, cognitief en motivationeel) tot betere leerprestaties leidt. De fysische context lijkt slechts in geringe mate bij te dragen aan het leerproces. Bij de semantische context is het mogelijk dat het verwerven van biomedische kennis in een klinische context kan leiden tot beter leerprestaties, maar we konden dit niet statistisch aantonen. Voor de studie naar de motivationele dimensie zijn de resultaten moeilijk te interpreteren.

De resultaten betekenen niet dat leren in een klinische context verbannen dient te worden uit het geneeskundecurriculum. We hebben geen duidelijk significant verschil kunnen aantonen, maar het is ook niet bewezen dat leerprestaties verminderen wanneer een meer verrijkte contextdimensie wordt aangeboden. Daarnaast 
blijven nog veel vragen onbeantwoord. Zo is in het proefschrift gekeken naar reproductie van kennis, niet zozeer toepassing of het beoefenen van vaardigheden. Het is denkbaar dat de resultaten op deze gebieden anders zijn. Kortom: onderzoek is nooit af! 